\title{
STRUCTURAL TYPIFICATION OF HERITAGE BUILDINGS USING MODERN TECHNOLOGIES FOR DIGITAL MANAGEMENT AND VISUALIZATION: PRELIMINARY APPLICATIONS IN SOUTHERN PERU
}

\author{
S. HUARANGA ${ }^{1 *}$, P. PÓRCEL ${ }^{1}$, C. YAYA $^{1}$, B. CASTAÑEDA $^{1}$ AND R. AGUILAR ${ }^{1}$ \\ ${ }^{1}$ Engineering Department, Civil Engineering Division \\ Pontificia Universidad Católica del Perú PUCP \\ Av. Universitaria 1801, San Miguel, Lima 32, Perú \\ e-mail: \{shuaranga,pporcel\}@pucp.pe; \{c.yaya, castaneda.b\}@pucp.edu.pe and raguilar@pucp.pe
}

Keywords: Structural typologies, HBIM, Augmented Reality, Andean churches

\begin{abstract}
Structural typologies represent a group of buildings with similar geometrical configuration and seismic performance. These typologies are normally used in the preliminary stages of structural assessment of building stocks since they provide an overview of quick results which guide subsequent studies of cases that resemble the types. This article provides a methodology of structural typification using modern technologies for digitalization and visualization of information based on the study of a representative sample of 22 churches located in the South Andean zone of Peru and considered as part of Peru's Cultural Heritage. For each church, the information has been acquired and digitally modeled through the integration of reverse engineering methods and Heritage Building Information Modelling (HBIM). Furthermore, in order to improve the visualization and interaction experience, a mobile application using Augmented Reality was developed. The use of these modern techniques allowed the management of the information, which enhanced the comprehension of the churches and thus enabled its further structural analyses. As a result, it has been identified 11 structural typologies of Andean churches, based on the material of its load bearing system, their architectural form and some geometrical particularities of its structural elements.
\end{abstract}

\section{INTRODUCTION}

The process of structural typification entails analyzing and classifying building stocks into types, according to relevant elements and geometrical features which influence their seismic behavior and structural capacity [2]. Structural typologies possess common attributes of the group of buildings they represent and their implementation in preliminary seismic assessment evaluations of a macroscale approach generate rapid results and guide further damage analysis [1]. Many post-earthquake studies corroborate that buildings belonging to the same structural typology behave the same manner and, consequently, develop similar collapse mechanisms [3].

To establish representative structural typologies of heritage buildings, it is important to have an adequate and standardized understanding of their structural system [4]. However, on several occasions, this information is non-existent or difficult to access due to the scarce and dispersed documentation recorded of their geometric, architectural and structural characteristics. These difficulties in understanding are intensified in the study of Andean churches because they are considered monumental buildings of complex geometry and architectural features built using multiple materials and no records of construction techniques [5]. 


\section{MODERN MANAGEMENT AND VISUALIZATION TECHNIQUES FOR HERITAGE BUILDINGS}

In recent years, rapid advances in technology have promoted the implementation of multidimensional and collaborative techniques in conservation and restoration projects of Cultural Heritage [6]. The use of these tools benefits structural assessment of ancient buildings by improving information management and visualization, which enhance their understanding and facilitates decision-making [7]. In this sense, Heritage Building Information Modelling (HBIM) and Augmented Reality (AR) are recently used in the study of heritage buildings. A proposal of the workflow of its combined employment is presented in Figure 1.

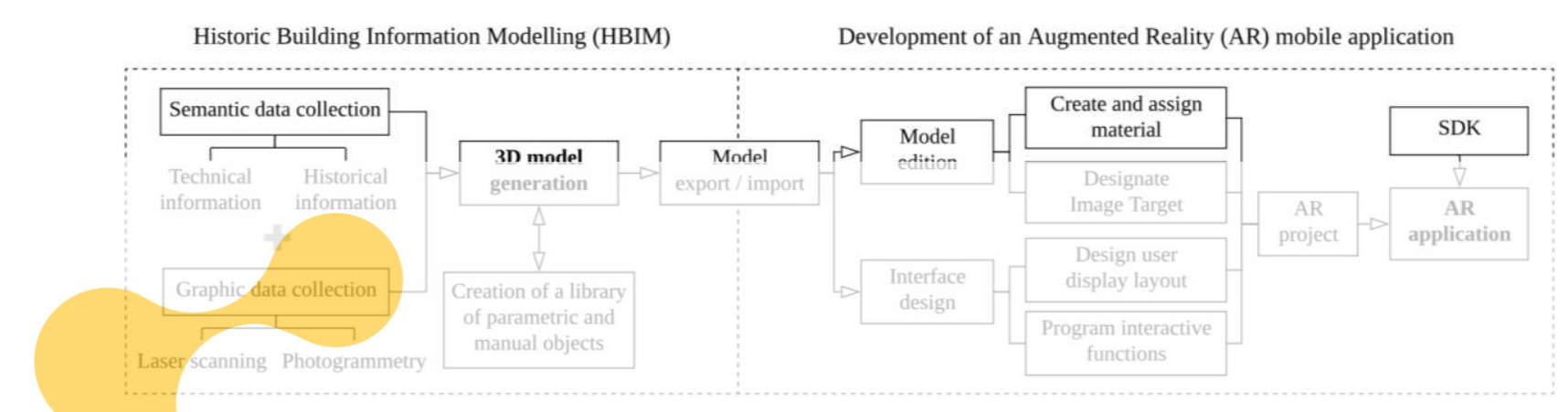

Figure 1: Procedure for digitization and representation using Augmented Reality of information from
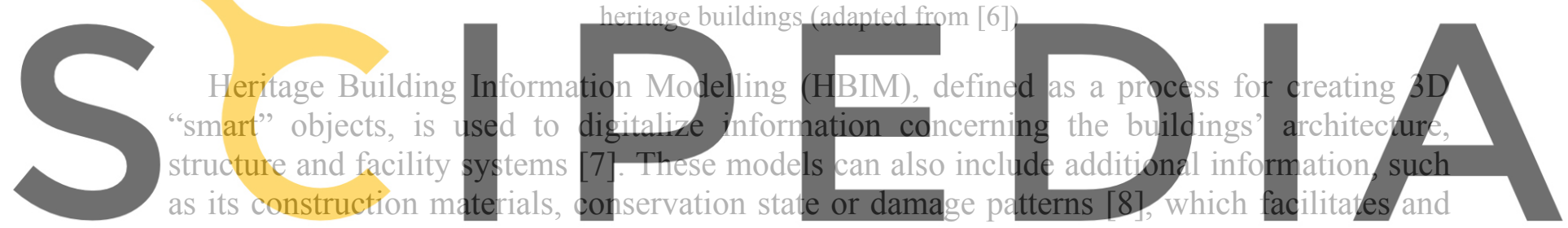

integrates the management of the construction processes and the maintenance of their facilities.

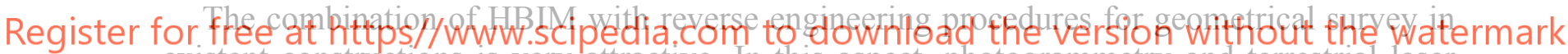
existent constructions is very attractive. In this aspect, photogrammetry and terrestrial laser scanning are commonly used, complemented with descriptive information from technical and historical sources [9], to obtain point clouds from which objects can be modeled using AEC (Architecture, Engineering, Construction) software [10]. These applications allow a virtual reconstruction of the buildings by the assemblage of smart objects that represent its structural elements. In this process, libraries of 3D objects related to databases can be make up in order to storage relevant information for subsequent analyses.

Augmented Reality (AR) is defined as the overlaying of digital information in the real world environment, improving the perception of the user and promoting real-time interaction [11]. AR can be displayed in handheld mobile devices' screen through the recognition of an Image Target [12]. To develop an AR application, is necessary to import 3D models into display engines and to carry out two steps. Firstly, 3D objects are assigned pre created materials and textures for its rendering and are designated to an Image Target. Secondly, the User Interface is designed by creating the display layout and by programming interactive functions. Software Development Kits, known as SDKs, facilitate the transition of AR projects from graphic engines to mobile operating systems (i.e. iOS or Android) where they will be executed [13]. They also allow their rendering and the tracking and the Image's Target recognition. 


\section{STRUCTURAL TYPIFICATION USING HBIM AND AUGMENTED REALITY}

Peru is recognized as a center of diffusion and reference of the colonial architecture in Andean region [14]. The first churches were the result of the combination of forms and styles imported from the Iberian Peninsula with local contributions, influenced by Peruvian idiosyncrasy and availability of resources in the area [15]. The present investigation is restricted to churches located in the region of Cusco for two reasons. First, Cusco, as the civil, political and ecclesiastical capital of the Spanish viceroyalty, was the main reference and promoter of the development and diffusion of culture, art and architecture in the region [16]-[18]. Second, after the earthquake of 1650 an ecclesiastical provision [17] made official the use of formal architectural and structural models from Cusco as references for the churches to be restored within the city and new constructions in the Andean region [18]. In the present work, a methodology of 3 stages was used for the structural typification of churches (see Figure 2).

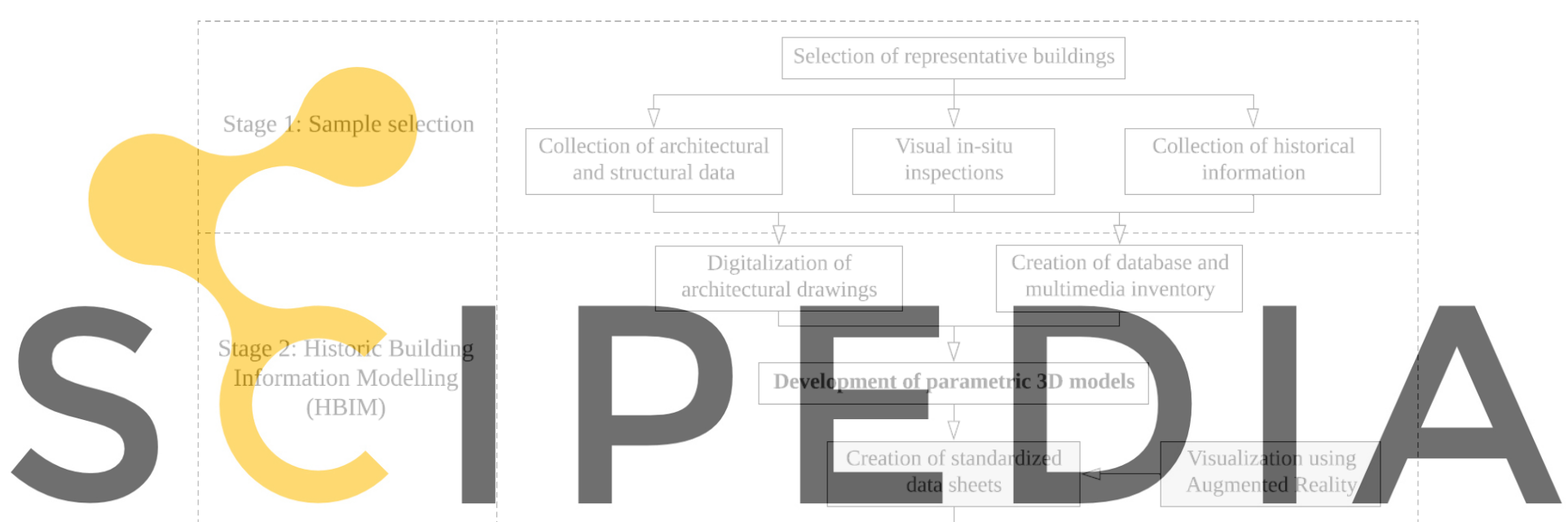

Register for free at https//www.scipedia.com to downfloction fyificatione criteriarsion without the watermark

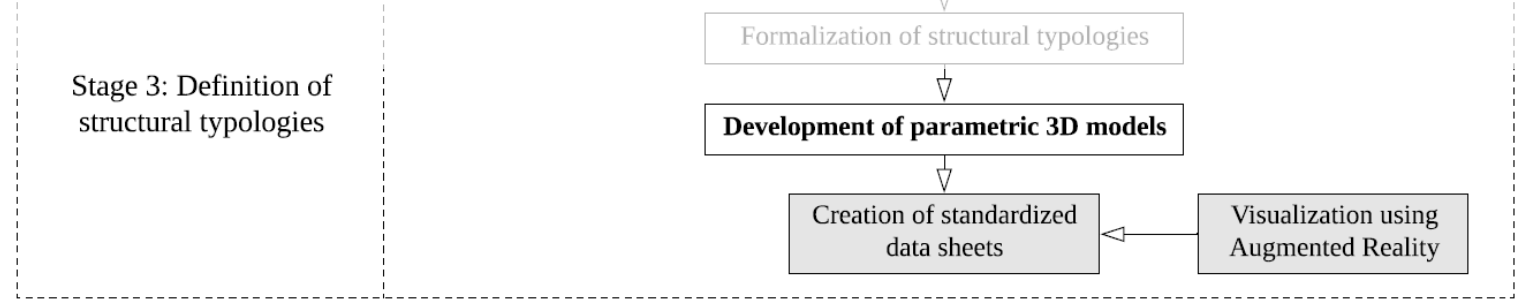

Figure 2: Methodology of structural typification using HBIM and AR

The first stage consisted on collecting information from a sample of 22 Andean churches using bibliography research and in-situ inspections. The information was digitized and stored in databases, which enabled the creation of 3D models of the churches. For each case study, a standardized data sheet including a wide description and documentation of its structural system was generated. In the third stage, the churches were analyzed and, according to three structural criteria, were typified. For each typology, 3D models were created for representing their typical and variable structural elements, which were presented in technical data sheets along with their 
description. Simultaneously to these stages, AR applications were developed to visualize and interact with the smart models of both, the churches of the sample and the proposed typologies.

\subsection{STAGE 1: SAMPLE SELECTION}

A sample of 22 churches located in the region of Cusco was selected due to the existence of historic precedents of their influence in the construction of religious buildings in all the Andean region [15-19]. Because of their importance in the region, these buildings possess available information regarding architecture and structural features, and some of them were object of study of previous structural assessments $[20,21]$. Likewise, these temples have a high tourist influx, which provides with extensive photographic records from their inside and outside. In all cases, the missing information was completed with visual inspections which were aimed at updating the architectural and structural information, revision of historical documents, and expanding the photographic record. Within this sample, $70 \%$ of the temples are located in the historical city center, while the remaining 30\% belong to rural areas.

\subsection{STAGE 2: HISTORIC BUILDING INFORMATION MODELLING}

The records of architectural drawings obtained were digitalized on CAD and the data collected from historical and touristic sources was condensed on digital databases and multimedia inventories. With these tools, the understanding of the churches was enhanced and thus allowed the creation of standardized data sheets with the descriptions of each case study.

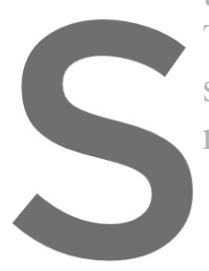
The development of smart $3 \mathrm{D}$ models was ca
sample of the modelling and implementation
resultant formulary is presented in Figure 3 .
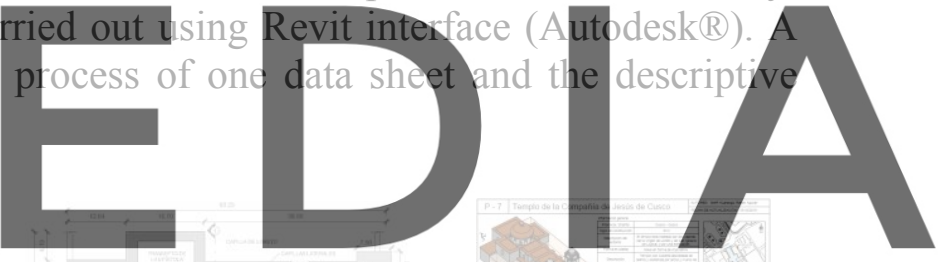

Register for free at https//www.scipedia.com to download the version without the watermark

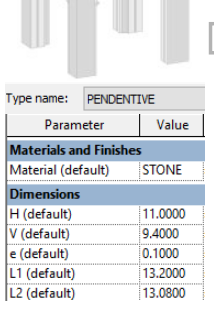

(a)

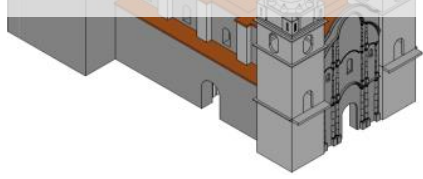

(b)

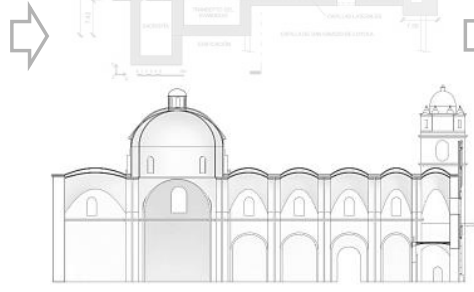

(c)

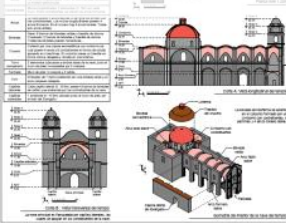

(d)

Figure 3: Inventory process of a religious building: the church of the Society of Jesus. (a) Modeling of parametric objects; (b) General 3D modeling; (c) Documentation; (d) Standardized technical data sheets

First, parametric and manual modeling of objects representing structural elements of the church were created according to the recurrence and complexity of its shape. For instance, the most common elements, such as arches or vaults, were modelled parametrically with the aim of using them on further models; whereas, particular elements, such as altarpieces or architectural details, were modeled based on the extrusion of profiles or manual creation of surfaces. The objects were then inserted and assembled in the software, in where they were 
grouped according to their structural functionality and type of material. Finally, descriptive data sheets were complemented with the documentation and measures obtained from the 3D model.

The 3D models were imported into Unity [22] for the development of an Augmented Reality experience (AR). They were edited in order to assign colors and textures to its structural elements, differentiating the type of material, and matched to an Image Target, which in this case were the descriptive data sheets. Simultaneously, the user interface, where the user observes and interacts with the structural elements of the 3D model, was developed. For each element two possible interactive functions were designed: the visualization of a pop-up screen where qualitative and quantitative information of the church is displayed, and the displacement in one of the 3D axis. Finally, the engine used Vuforia and Android's SDKs to build the project for Android platform, creating the mobile augmented reality application, as shown in Figure 4.

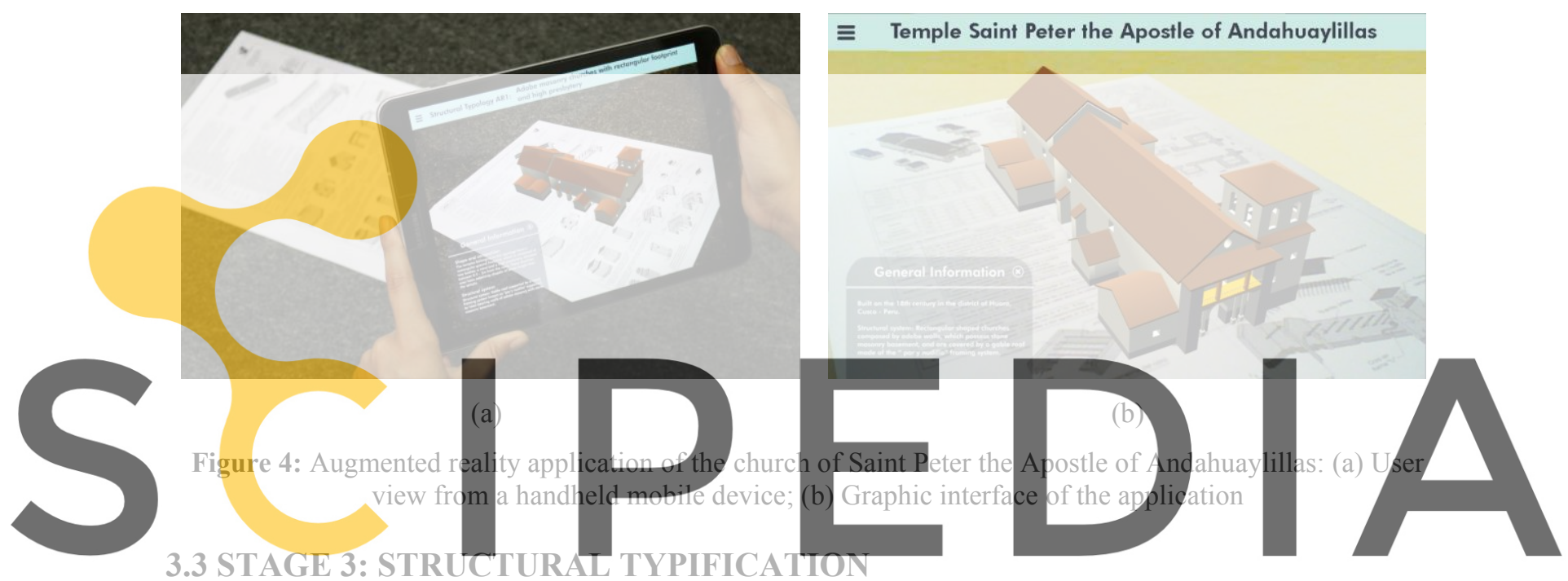

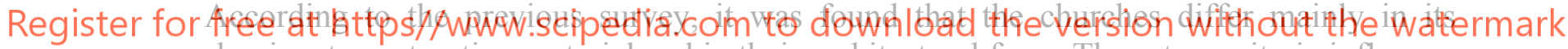
predominant construction material and in their architectural form. These two criteria influence its seismic performance and thus were selected the structural typification of Andean churches. Regarding its structural system, these buildings are composed of bearing walls made of three types of masonry (see Figure 5).

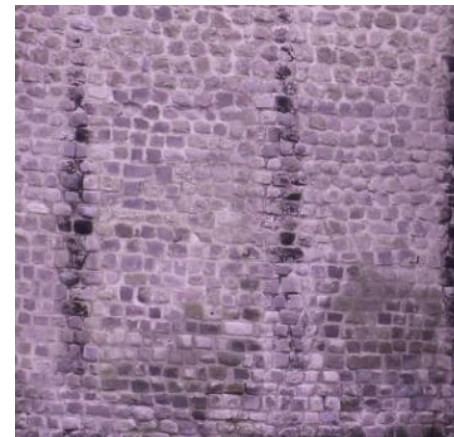

(a)

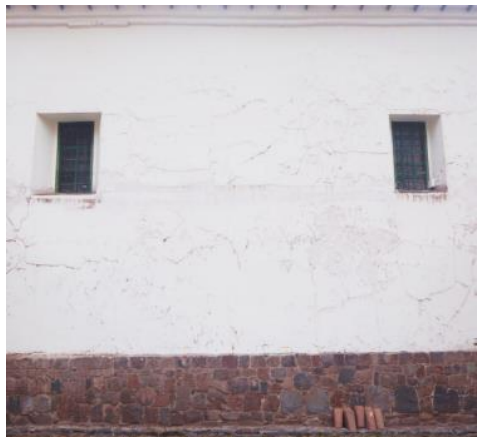

(b)

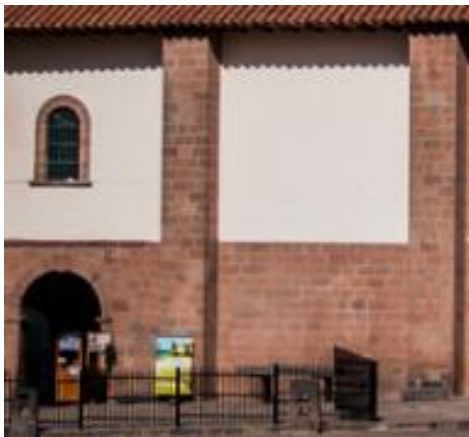

(c)

Figure 5: Types of masonry in Andean churches: (a) Stone masonry in Society of Jesus church; (b) Adobe masonry in St. Peter the Apostle church of Andahuaylillas; (c) Mixed masonry in St. Christopher church 
Stone masonry walls are composed of rough or polished stone blocks joined with lime. Adobe masonry walls are composed of adobe blocks joined with mortar, supported by a basement of stone masonry 1-2m high. Finally, mixed masonry is defined as a combination of the two previous types, with a predominance of over $70 \%$ of adobe masonry. Within the sample, $50 \%$ of the churches possess adobe masonry walls, $32 \%$ possess stone masonry walls and $18 \%$ possess mixed masonry walls.

Secondly, the field investigation identified four categories of the architecture's distribution according to the buildings' cross section and building plan's shape (see Table 1). Rectangular shaped churches are conformed by a single nave that possess arches that support the vaults along with the bearing walls. The cross-shaped type churches are composed by a rectangular nave crossed perpendicularly by a smaller and rectangular nave called transept. The gallery where the two main axis of the naves crosses is called crossing and is usually covered by a dome, higher that the vaults of other galleries. The Basilical and Hall categories possess a main nave flanked by lateral naves. Basilical shaped churches possess lateral naves almost half of the height of the main nave, whereas Hall shaped temples possess naves with the same height.

Table 1: Categories of churches according to their architectural distribution

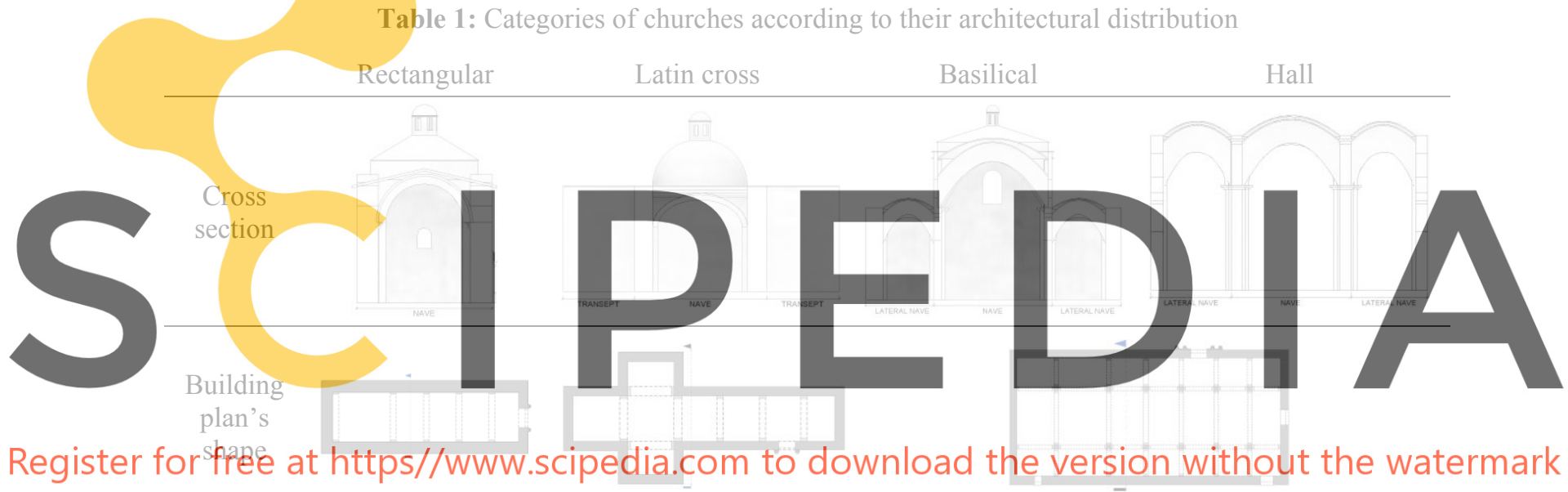

Finally, three particularities of the churches' structural elements were used as final criteria in the typification: vertical irregularities between the nave and the presbytery, variations in mixed masonry and presence of side chapels along longitudinal walls. In the group of adobe rectangular-shaped churches, a subgroup of buildings with the presbytery elevated between 1$2 \mathrm{~m}$ above the nave was identified. In this case, the presence of triumphal arches at the intersection of the nave and the presbytery is permanent, whereas elongated nave temples are characterized by occasionally having the triumphal arch. In mixed masonry churches, two possible wall's composition were observed: the existence of high foundations, almost half the height of the wall, and facade walls made entirely of stone masonry. Finally, in stone churches, it was observed that the presence of side chapels, defined as rooms with spans no greater than $1-2 \mathrm{~m}$, modify the continuity of the churches' longitudinal walls in order to connect them with the nave. The wall's variation depends on their architectural distribution. For example, rectangular-shaped churches possess walls with a gap at the middle of the nave (see typology SR-2 of Table 2), whereas cross-shaped and hall-shaped churches possess continuous walls with big openings (see typologies SLC-2 and SH of Table 2). In both cases, the load of the roof 
at the discontinuous sections are concentrated to the internal arches of the nave, which are normally reinforced in the outside by aligned buttresses.

Based on these criteria, 11 structural typologies were identified within the study sample, as shown in Figure 6 and Table 2. In the schematic 3D views, stone and adobe masonry and bricks are differentiated by the usage of colors that resemble these materials. Moreover, the exterior variable elements of each typology, such as bell towers or adjacent chapels, are set apart from typical structural elements by being colored by a light gray tone. The typologies SR-2, SLC-2 and SH present their adjacent chapels extruded from their original position to show their effect on the continuity of longitudinal walls.

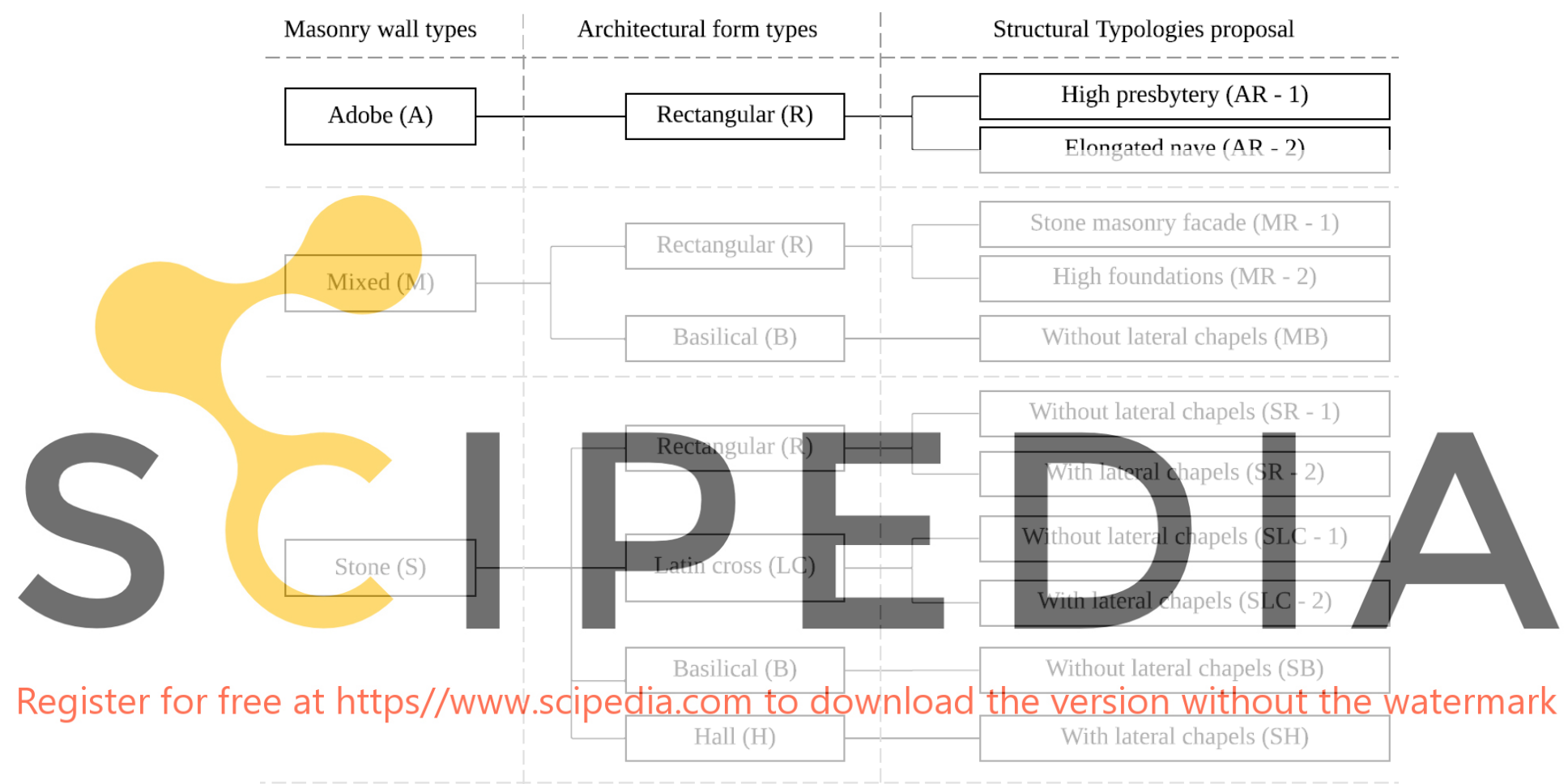

Figure 6: Summary of proposed structural typologies

The process of developing the AR application of the structural typologies is similar to the application made for the 22 sample churches. The differences lie in the interactive functions of the user interface given that the description of structural typologies is more extend due to typical and variable characteristics they represent from their group. The application uses the descriptive standardized sheet as Image Target, as seen in Figure 8a. The general information of the type and the description of its structural elements can be displayed from the main menu, located next to the title of the application. Typical and variable elements of the typologies can be displayed by using it correspond button, as shown in Figure 8b. The names of the structural elements are shown in labels the user can click in order to see more details: a window with further descriptive details appears at one side of the screen and the structural element is highlighted from the rest of the temple (see Figure 8c). In the case of variable structural elements, such as bell towers, choirs or facades, the emergent window includes information and schemes of their possible variations (see Figure 8e). 
Table 2: Schematic 3D views of the proposed structural typologies
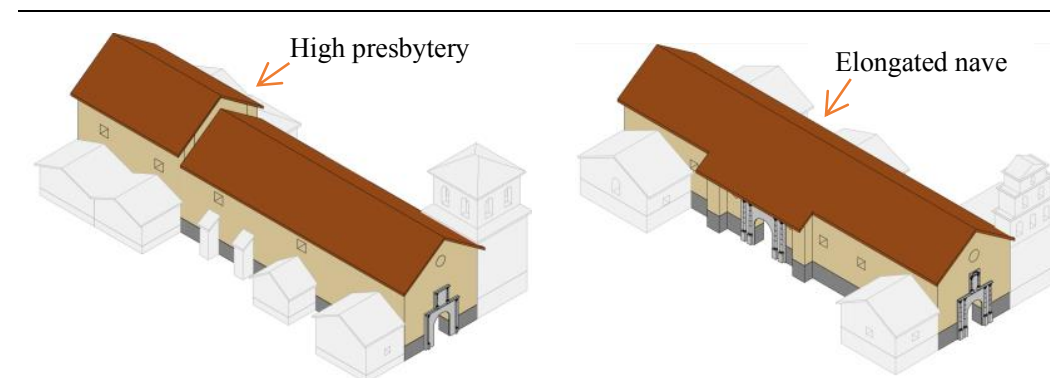

AR - 1

AR - 2

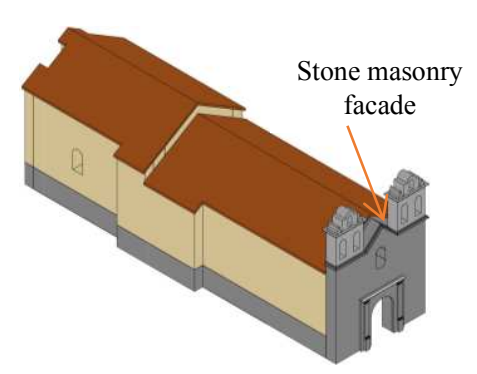

MR - 1

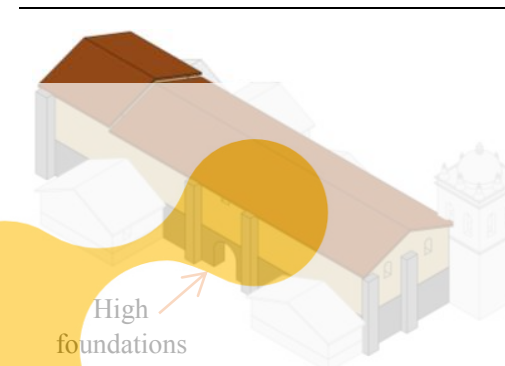

MR - 2
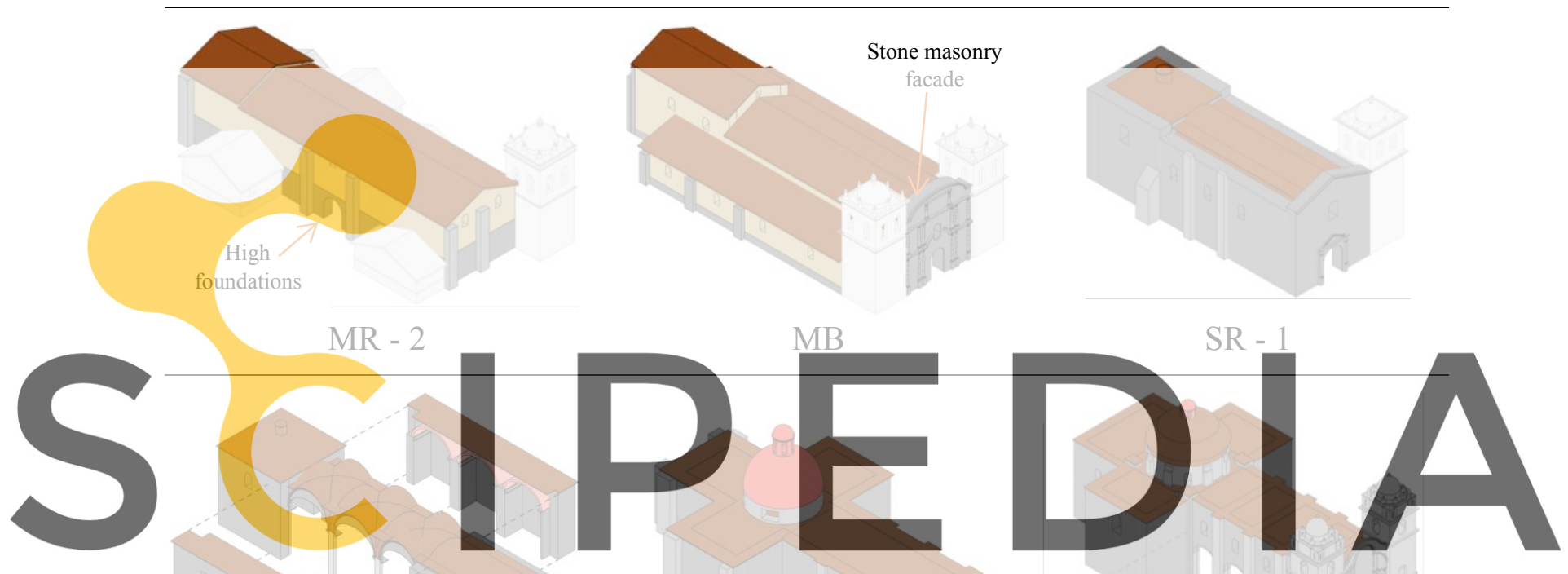

Register for free at https//www.scipedia.com to download the version without the watermark

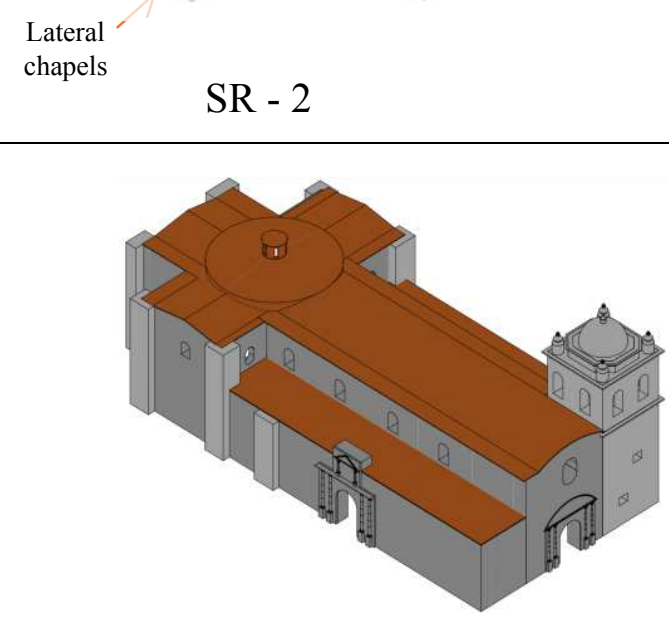

SB
Lateral $\lambda$

chapels $\quad \mathrm{SLC}-2$

SLC - 1

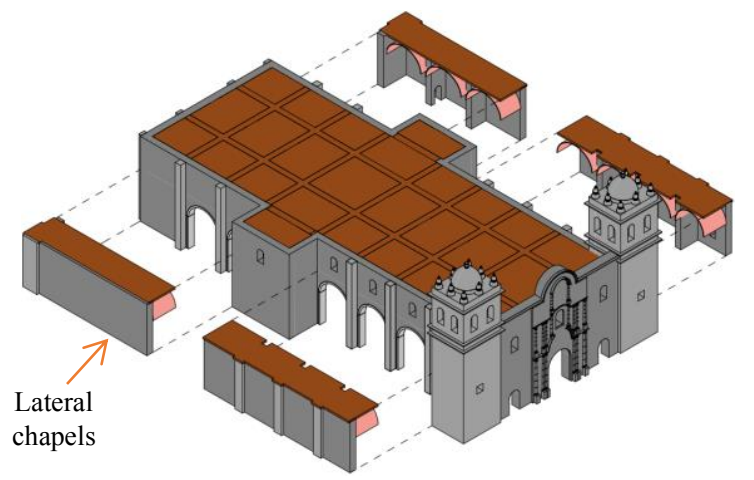

$\mathrm{SH}$ 

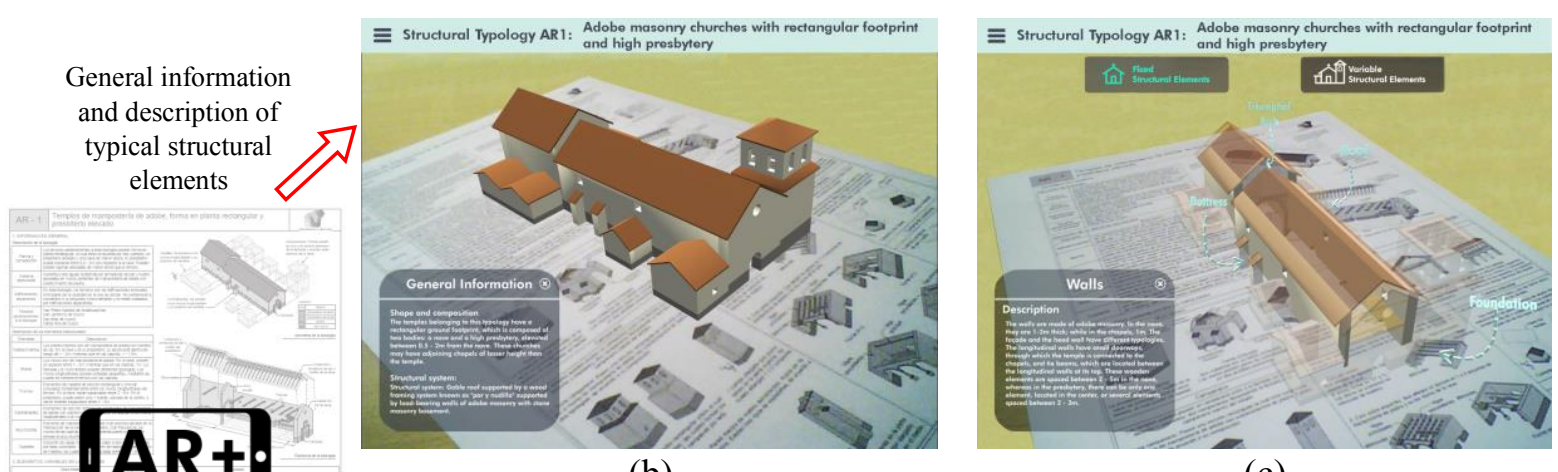

(b)

(c)

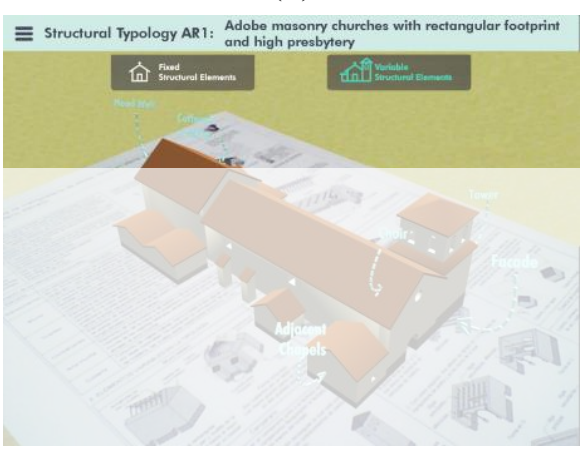

(d)

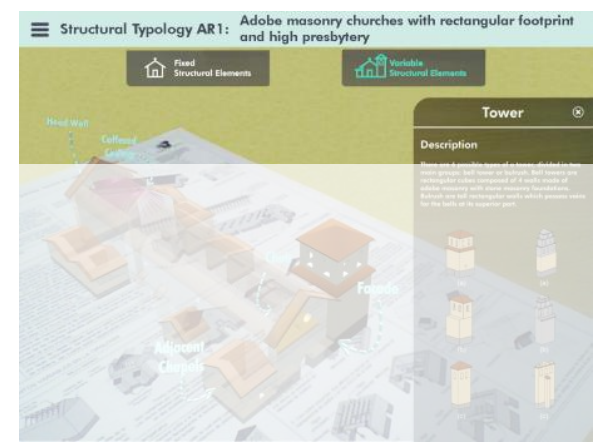

(a)
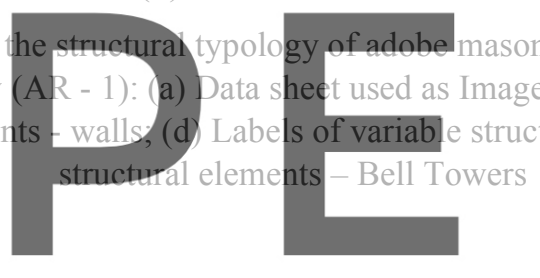

(e)
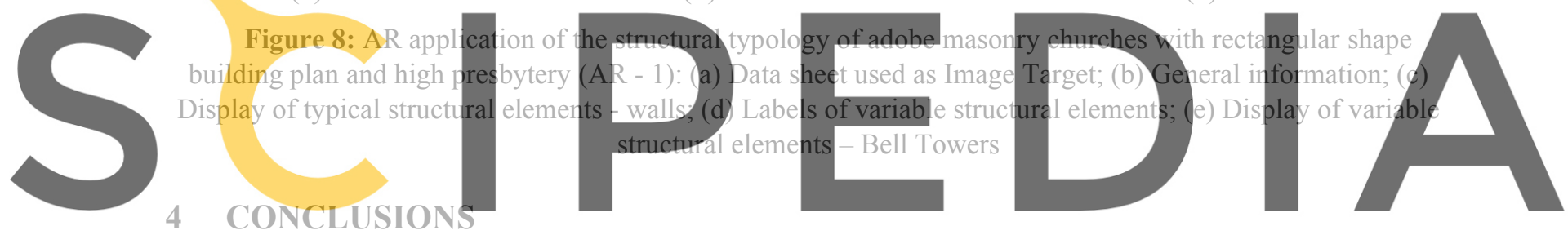

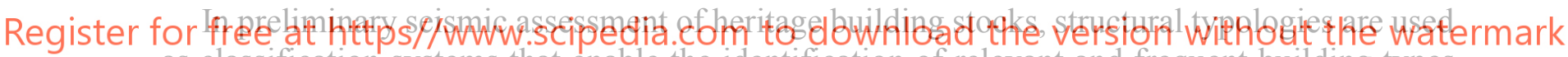

as classification systems that enable the identification of relevant and frequent building types

in national scales. This investigation provides a methodology of structural typification

implementing HBIM and Augmented Reality to enhance the information management, description and visualization of heritage buildings. As a result, 11 structural typologies were established, and its typical and variable structural elements were described and documented in standard technical sheets. Furthermore, these sheets were assembled in a condensed repository of data storage interconnected to smart 3D objects' libraries. This investigation adds value to subsequent individual studies of these churches by providing relevant information of their structural system and 3D models that can be used in further numerical evaluations, so manual and time-consuming modelling does not need to be carried out. The development of the Augmented Reality (AR) application was crucial for visual representation and interaction of the digital information modelled. The irregularities and complex morphology of the studied churches can be easily understood by the dynamism and interactivity that the application provides through its user interface and functions. The quantification of the impact of the application on non-specialist users will determine the effectiveness of the method proposed and shall give a lead on the improvement and refinement of the AR application. Future works should 
also consider the validation of the proposed structural typologies for its implementation in international scales.

Acknowledgements. This research was performed by the Laboratory of Engineering and Heritage at PUCP. The authors acknowledge the funding provided by DGI-PUCP in the framework of the project $\mathrm{N}^{\mathrm{o}} 2018-601$.

\section{REFERENCES}

[1] Rusell, A. Characterization and seismic assessment of unreinforced masonry buildings. PhD thesis, University of Auckland: Auckland, New Zealand (2010).

[2] ICOMOS. Recommendations for the analysis, conservation and structural restoration of architectural heritage. Paris International Council on Monuments and Sites (2001).

[3] NIKER (New Integrated Knowledge Based Approaches to the Protection of Cultural heritage from Earthquake-induced Risk). Deliverable 3.1: Inventory of earthquake-induced failure mechanisms related to construction types, structural elements and materials. Università di Padova - European Commission (2010).

[4] ICOMOS. Principles for the analysis, conservation and structural restoration of architectural heritage. Paris International Council on Monuments and Sites (2001).

[5] Augusti, G., Ciampoli, M. and Giovenale, P. Seismic vulnerability of monumental buildings. Structural Safety, 23 (2001), 3: pp. 253-274.

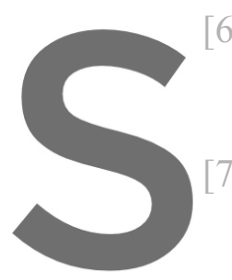

[6] López, F., Lerones, P., Llamas, J., Gómez-García-BerneJ heritage building Interaction, 2 (2018) Murphy, M., McGo Journal of Photogran
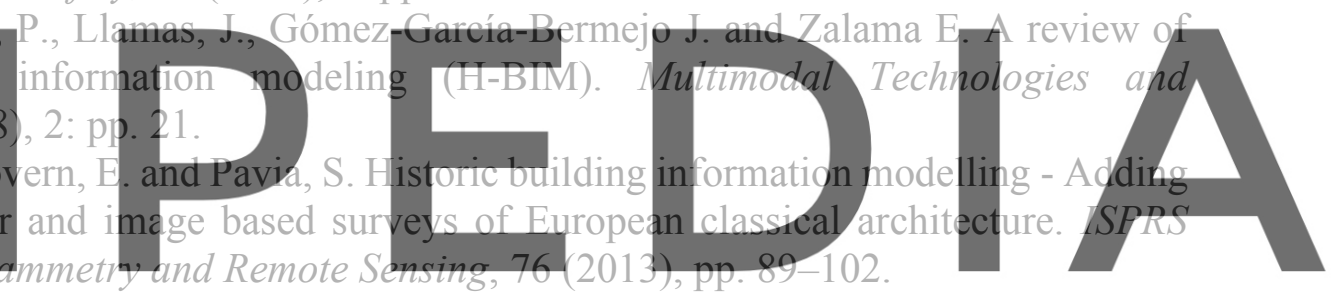

[8] Pocobelli, D. P., Boehm, J., Bryan, P., Still, J. and Grau-Bové J. BIM for heritage science:

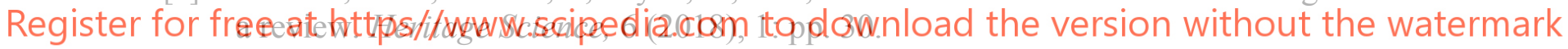

[9] Yastikli, N. Documentation of cultural heritage using digital photogrammetry and laser scanning. Journal of Cultural Heritage, 8 (2007), 4: pp. 423-427.

[10] Logothetis, S., Delinasiou, A. and Stylianidis E. Building information modelling for cultural heritage: a review. In: ISPRS Annals of the Photogrammetry, Remote Sensing and Spatial Information Sciences: $25^{\text {th }}$ International CIPA Symposium, Taipei (2015).

[11] Van Krevelen, D. W. F. and Poelman, R. A survey of augmented reality technologies, applications and limitations. Int. Journal of virtual Reality, 9 (2010) 2: pp. 1-20.

[12] Linowes, J. and Babilinski, K. Augmented Reality for Developers: Build practical augmented reality applications with Unity, ARCore, ARKit, and Vuforia. Packt Publishing (2017).

[13] Amin, D. and Govilkar, S. Comparative study of augmented reality SDKs. Int. Journal on Computational Sciences \& Applications, 5 (2015), 1: pp. 11-26.

[14] Chara, O. Arquitectura religiosa española en la ciudad del Cusco en los siglos XVI-XVII ('Spanish religious architecture in the city of Cusco in the 16th-17th centuries'). Cabildo Insular de Fuerteventura Vol II. (1992), 5: pp. 367-388.

[15] Chara, O. and Caparó, V. Iglesias del Cusco : historia y arquitectura ('Churches of Cusco : history and architecture'). Universidad Nacional San Antonio Abad del Cusco (1998). 
[16] Cosme, C. La influencia hispano árabe en la arquitectura peruana ('The Hispanic-Arabic influence on Peruvian architecture'). Revista de Arquitectura, 3 (2016), 1: pp. 99-118.

[17] Municipalidad del Cusco. Cusco y la herencia del barroco andino ('Cusco and the Andean Baroque heritage'). Cusco (2013).

[18] Segre, R. América Latina en su arquitectura ('Latin America in its architecture'). Siglo XXI editores (1996).

[19] Kubiak, E. La iglesia de los Jesuitas en Cusco como un modelo para la arquitectura de la región ('The church of the Jesuits in Cusco as a model for the architecture of the region'). Latin American Art, 2 (2012), pp: 35-66.

[20] Marques, R., Ivancic, S., Briceño, C., Aguilar, R., Perucchio, R. and Vargas, J. Study on the seismic behaviour of St. Peter the Apostle Church of Andahuaylillas in Cusco, Peru. In: Proc of the SAHC 2010: $7^{\text {th }}$ International Conference on Structural Analysis of Historical Constructions, Mexico (2014), pp: 14-17.

[21] Aguilar, R., Noel, M. F. and Ramos, L. Integration of reverse engineering and non-linear numerical analysis for the seismic assessment of historical adobe buildings. Automation in Construction, 98 (2019), pp: 1-15.

[22] Unity 2019. Unity Technologies user's Manual, release 2019.2.13f1. United States. 